OPEN ACCESS

Edited by:

Essaid A. Barka,

Reims University, France

Reviewed by:

Maria J. Pozo,

Consejo Superior de Investigaciones

Científicas, Spain

Blanca B. Landa,

Institute for Sustainable Agriculture -

Consejo Superior de Investigaciones

Cientificas, Spain

*Correspondence:

Marc Bardin

Institut National de la Recherche

Agronomique, UR407, Plant

Pathology Unit, 67 Allée des Chênes,

CS60004, F-84140 Montfavet, France

marc.bardin@avignon.inra.fr

Specialty section:

This article was submitted to

Plant Biotic Interactions,

a section of the journal

Frontiers in Plant Science

Received: 27 February 2015 Accepted: 09 July 2015

Published: 27 July 2015

Citation:

Bardin M, Ajouz S, Comby M, Lopez-Ferber M, Graillot B, Siegwart $M$ and Nicot PC (2015) Is the efficacy of biological control against plant diseases likely to be more durable than that of chemical pesticides?

Front. Plant Sci. 6:566.

doi: 10.3389/fpls.2015.00566

\section{Is the efficacy of biological control against plant diseases likely to be more durable than that of chemical pesticides?}

\author{
Marc Bardin ${ }^{1 *}$, Sakhr Ajouz ${ }^{1}$, Morgane Comby ${ }^{1}$, Miguel Lopez-Ferber ${ }^{2}$, Benoît Graillot ${ }^{2,3}$, \\ Myriam Siegwart ${ }^{4}$ and Philippe C. Nicot ${ }^{1}$
}

\begin{abstract}
'Plant Pathology Unit, Institut National de la Recherche Agronomique, UR407, Montfavet, France, ${ }^{2}$ Laboratoire de Génie de I'Environnement Industriel, Ecole des Mines d'Alès, Institut Mines-Telecom, Alès, France, ${ }^{3}$ Natural Plant Protection, Arysta LifeScience Group, Pau, France, ${ }^{4}$ Plantes et Systèmes de Culture Horticoles Unit, Institut National de la Recherche Agronomique, UR1115, Avignon, France
\end{abstract}

The durability of a control method for plant protection is defined as the persistence of its efficacy in space and time. It depends on (i) the selection pressure exerted by it on populations of plant pathogens and (ii) on the capacity of these pathogens to adapt to the control method. Erosion of effectiveness of conventional plant protection methods has been widely studied in the past. For example, apparition of resistance to chemical pesticides in plant pathogens or pests has been extensively documented. The durability of biological control has often been assumed to be higher than that of chemical control. Results concerning pest management in agricultural systems have shown that this assumption may not always be justified. Resistance of various pests to one or several toxins of Bacillus thuringiensis and apparition of resistance of the codling moth Cydia pomonella to the C. pomonella granulovirus have, for example, been described. In contrast with the situation for pests, the durability of biological control of plant diseases has hardly been studied and no scientific reports proving the loss of efficiency of biological control agents against plant pathogens in practice has been published so far. Knowledge concerning the possible erosion of effectiveness of biological control is essential to ensure a durable efficacy of biological control agents on target plant pathogens. This knowledge will result in identifying risk factors that can foster the selection of strains of plant pathogens resistant to biological control agents. It will also result in identifying types of biological control agents with lower risk of efficacy loss, i.e., modes of action of biological control agents that does not favor the selection of resistant isolates in natural populations of plant pathogens. An analysis of the scientific literature was then conducted to assess the potential for plant pathogens to become resistant to biological control agents.

\section{Keywords: biocontrol, durability, plant pathogen, resistance, efficacy}

\section{Introduction}

The durability of a control method for plant protection is defined as the persistence of its efficacy in space and time. Erosion of effectiveness of conventional plant protection methods has been widely studied in the past. The durability of chemical control has for instance been studied because of the frequent and recurrent apparition of resistance to fungicides in major plant 
pathogenic fungal populations (Brent and Hollomon, 2007). The breakdown of varietal resistance, especially that conferred by major resistance genes, has also been widely studied for plant pathogens (McDonald and Linde, 2002). In contrast, the durability of biological control has long been assumed to be higher than that of chemical control (Holt and Hochberg, 1997). However, recent results concerning pest management in agricultural systems have shown that this assumption may not always be justified.

The most striking example may be the development of resistance to the most widely used bio-insecticide in the world. Resistance to one or several toxins produced by the bacterium Bacillus thuringiensis $(B t)$ has been described shortly after the market approval of products based on various strains of this bacterium. McGaughey was the first to observe resistance in the field to $B t$ toxins in the Indian meal moth Plodia interpunctella, a major post-harvest pest of grain (McGaughey, 1985; McGaughey and Johnson, 1992). Two other species have shown to present a resistance to $B t$-formulation applied in the field: Plutella xylostella (Tabashnik, 1994) and Trichoplusia ni (Janmaat and Myers, 2003). Resistance of pests to other biocontrol agents has also been reported, one example is the codling moth Cydia pomonella. A granulovirus preparation has been used for 15 years as a bioinsecticide for its control and it is estimated that this product was applied to more than 100,000 ha of orchards in Europe and to two to three million ha worldwide, with a market steadily increasing due to its effectiveness and environmental safety (Eberle and Jehle, 2006; Asser-Kaiser et al., 2007). In 2004 insect populations with low susceptibility to the virus were detected for the first time in France, Italy, and Germany in pome fruit orchards (Fritsch et al., 2005; Eberle and Jehle, 2006; Sauphanor et al., 2006; Berling et al., 2009).

In contrast with the situation for pests, the durability of biological control of plant diseases has hardly been studied and no scientific paper proving the loss of efficiency of biocontrol agents against plant pathogens in practice has been published so far. This may be related to the limited use of biological control against plant diseases in practice until recently (Nicot et al., 2011a). A bibliographical study conducted in the framework of the European project ENDURE (European Network for Durable Exploitation of Crop Protection Strategies) established that despite the large amount of microorganisms potentially candidate for biological control (Nicot et al., 2011a), they are still few biocontrol agents registered against plant diseases in the European Union (Heilig et al., 2011).

However, several studies reported the inconsistency of efficacy of various biocontrol agents when introduced under commercial field conditions-being less effective or completely ineffectiveeven though their efficacy was very good in controlled conditions (Shtienberg and Elad, 1997; Guetsky et al., 2001; Mark et al., 2006; Nicot et al., 2011b). This variability of efficacy is generally attributed to climatic variations (temperature, humidity, radiation) encountered in field conditions, a lack of ecological competence (survival, colonization ability) of the biocontrol agent, intrinsic traits of the antagonistic microbe (variable production of required metabolites or enzymes) and/or an unstable quality of the formulated product (Elad and Stewart,
2004; Mark et al., 2006; Ruocco et al., 2011). However, reduction of efficacy in the field may also result from the diversity of sensitivity of plant pathogens to biocontrol agents, with the existence of less sensitive isolates in natural populations of plant pathogens.

The durability of biological control against plant pathogens may be related to specific traits of the plant pathogen such as genetic diversity and ability to evolve in response to a selection pressure. This is affected by population genetic processes including mutation, population size, recombination, gene flow and selection. This point was extensively studied to achieve durable plant disease resistance in agriculture (McDonald and Linde, 2002; McDonald, 2014). Thus, McDonald and Linde (2002) have hypothesized that populations of plant pathogens with high evolutionary potential are more likely to overcome a varietal resistance. The same assumption can be proposed for the development of resistance to biocontrol agents.

The durability of biological control against plant pathogens may also be related to the selection pressure exerted by the biocontrol agent. This selection pressure clearly depends on the extent of use of biocontrol agents in practice (surfaces treated, doses of application...). It may also depend on the specific mode of action of biocontrol agents. Various modes of action are involved in the protective effect of biocontrol agents against plant pathogens. Although the number of studies done on this subject is important, knowledge of the precise mode of action of biocontrol agents is still partial. However, it is generally considered that there are three main ways for a biocontrol agent to control a plant pathogen (Jacobsen, 2006; Alabouvette et al., 2009): first, by acting directly on the plant pathogen, through antibiosis, competition for nutrient or space, or parasitism; secondly by interfering with the mechanisms of pathogenesis of the plant pathogen, and thirdly by modifying the interaction of the plant pathogen with its plant host for instance through the induction of local or systemic acquired resistance. These modes of action are not incompatible, they can instead be complementary and a single species or a single strain of a biocontrol agent may act with several of these modes of action (Janisiewicz and Korsten, 2002). A given biocontrol agent may therefore operate through several mechanisms potentially expressed successively, simultaneously or synergistically and possibly depending on the environmental conditions encountered. Nevertheless, it is not yet clear if biocontrol agents have a dominant mode of action and under what conditions they switch from a mode of action to another. Even though all biocontrol agents should create selection pressure on target populations of plant pathogens once treatments are applied in the field, some modes of action may present a clear opportunity for pathogens to evolve resistance.

The main objective of this review is to assess the potential for plant pathogens to become resistant to biocontrol agents. To this end, an analysis of the scientific literature was conducted and scientific papers reporting the diversity of efficacy of biocontrol agents toward plant pathogens or those describing the ability of plant pathogens to produce natural mutants with reduced susceptibility under the selection pressure exerted by biocontrol 
TABLE 1 | Scientific papers published between 1973 and 2014 exploring the diversity of sensitivity of biological control against plant diseases analyzed in the review.

Number of references (Number of species*)

\begin{tabular}{lll}
\hline Plant pathogens & & \\
Bacteria & 4 & $(4)$ \\
Fungi & 19 & $(13)$ \\
Oomycetes & 5 & $(2)$ \\
Biocontrol agents & & \\
Virus & 3 & $(2)$ \\
Bacteria & $14 \quad(>18)$ \\
Fungi & 8 & $(>8)$ \\
Plant extract & 3 & $(3)$ \\
Mode of action of biocontrol agents & \multicolumn{2}{c}{} \\
Antibiosis & 16 & \\
Hyperparasitism & 6 &
\end{tabular}

*Number of microbial or botanical species evaluated for the plant pathogens and the biocontrol agents.

agents were analyzed. The link between a potential loss of efficacy of a biocontrol agent and its mode of action was carefully explored.

\section{Survey of the Scientific Literature Regarding the Durability of Biological Control Against Plant Diseases}

Identifying publications focused on this topic proved to be a challenging task. A survey of the Web of Science database between 1973 and the end of 2014, using the keyword combination [(biological control OR biocontrol OR antagonist*) AND ((pathogen OR disease) AND plant)], yielded 7872 references on biological control against plant diseases. Entering keywords describing the diversity of efficacy of biocontrol agents toward plant pathogens, i.e., [(divers ${ }^{\star}$ OR variab ${ }^{\star}$ OR variation) AND (resist* OR toleran* OR susceptib* OR sensitiv ${ }^{\star}$ OR insensitiv OR defense)], allowed to refine this survey to 593 references. However, the analysis of this subset yielded only six relevant references. A second subset was generated from the initial 7872 references by entering keywords describing the durability of efficacy of biocontrol agents toward plant pathogens, i.e., (durability OR durable OR sustainable OR sustainability). Among the 274 references obtained, only one was relevant. Efforts to improve the keyword combinations failed to yield any additional references, a situation presumably reflecting the scarcity of studies specifically dedicated to this topic. The set of seven references was then complemented with studies including a comparison of biocontrol efficacy for two or more strains of a given plant pathogen. Attempts to automate this search with keywords failed, probably due to the fact that such comparisons were not the focus of these studies. Eventually, additional references were obtained through direct consultation with scientists implicated in biocontrol of plant pathogens. It is thus likely that the final set of 30 references analyzed in the present review may not be exhaustive, but it already provided quite illustrative examples (Table 1). The vast majority of the publications provided information on the diversity of sensitivity to biocontrol agents or plant extracts among isolates of a given plant pathogen and only three publications concerned the ability of plant pathogens to adapt to biological control. Biocontrol agents described in the references have been classified according to their modes of action (basically antibiosis, hyperparasitism, competition, and induced resistance).

\section{Diversity of Sensitivity of Plant Pathogens to Biocontrol Agents}

Possible loss of efficacy of a biocontrol agent could result from the pre-existence of isolates with low susceptibility in natural populations of plant pathogens. Published studies that evaluated the diversity of sensitivity to biocontrol agents within a plant pathogen species were examined separately, according to the mode of action of the biocontrol agent or to the type of test realized.

\section{In Vitro Variation of Sensitivity of Plant Pathogens to Antimicrobial Compounds Produced by Biocontrol Agents}

Studies highlighting the variation in sensitivity to antimicrobial compounds produced by antagonistic microorganisms are listed in Table 2. Six different antimicrobial compounds have been tested against five species of plant pathogens. For a given species, the number of tested isolates ranged from 3 to 204 .

Among 66 isolates of Gaeumannomyces graminis var. tritici, the causal agent of take-all of wheat, diverse levels of sensitivity were observed toward phenazine-1-acide carboxylique (PCA) and 2,4diacetylphloroglucinol (2,4-DAPG), two compounds produced by antagonistic strains of fluorescent Pseudomonas spp. present in the wheat rhizosphere (Mazzola et al., 1995). One isolate of G. graminis var. tritici, was resistant to both antibiotics and could not be controlled effectively by the biocontrol agent in the rhizosphere of wheat plants. This led Mazzola et al. (1995) to speculate that massive use of these antibiotic-producing biocontrol agents might eventually result in the selection of G. graminis var. tritici populations resistant to these biocontrol agents. Diversity in the sensitivity to 2,4-DAPG was also found in a collection of 117 isolates of the fungal plant pathogen Fusarium oxysporum, with approximately $17 \%$ of the isolates being naturally tolerant (Schouten et al., 2004). The least sensitive isolates of $F$. oxysporum were able to withstand a 10-fold higher concentration of 2,4-DAPG than the lethal concentration used for isolates with the highest level of sensitivity. No correlation was found between the geographic origin of strains and their tolerance to 2,4-DAPG, suggesting that this tolerance was widely distributed worldwide among different subpopulations of $F$. oxysporum. A wide range of sensitivity was also reported in Botrytis cinerea to pyrrolnitrin, an antimicrobial compound produced by several antagonistic bacterial species including Serratia plymuthica and various Pseudomonads (Ajouz et al., 2011b). Among 204 isolates of B. cinerea, differing in their geographic origin and host of isolation, several had a significantly reduced sensitivity to pyrrolnitrin, with a resistance factor reaching 8.4-fold compared to the most sensitive isolates. These 
TABLE 2 | Examples highlighting the variation in sensitivity of plant pathogens to antimicrobial compounds produced by biological control agents.

\begin{tabular}{|c|c|c|c|c|c|}
\hline $\begin{array}{l}\text { Compounds } \\
\text { evaluated }^{1}\end{array}$ & $\mathrm{BCA}^{2}$ & Plant pathogen & $\begin{array}{l}\text { Number of } \\
\text { isolates }\end{array}$ & Main results & Reference \\
\hline 2,4-DAPG & Pseudomonas spp. & $\begin{array}{l}\text { Gaeumannomyces } \\
\text { graminis var. tritici }\end{array}$ & 66 & $\begin{array}{l}\text { Diverse levels of sensitivity; some isolates not } \\
\text { controlled in the rhizosphere of wheat. }\end{array}$ & Mazzola et al. (1995) \\
\hline 2,4-DAPG & $\begin{array}{l}\text { Pseudomonas } \\
\text { fluorescens }\end{array}$ & Fusarium oxysporum & 117 & $17 \%$ of isolates naturally tolerant $\left(\mathrm{RF}^{3} \approx 10\right)$ & Schouten et al. (2004) \\
\hline 2,4-DAPG & Pseudomonas spp. & Pythium spp. & 13 species & $\begin{array}{l}P . \text { volutum is the most sensitive, } P \text {. deliense is the } \\
\text { most resistant; various isolates of } P \text {. ultimum var. } \\
\text { sporangiiferum differ in sensitivity. }\end{array}$ & De Souza et al. (2003) \\
\hline PCA & Pseudomonas spp. & $\begin{array}{l}\text { Gaeumannomyces } \\
\text { graminis var. tritici }\end{array}$ & 66 & $\begin{array}{l}\text { Diverse levels of sensitivity; some isolates not } \\
\text { controlled in the rhizosphere of wheat. }\end{array}$ & Mazzola et al. (1995) \\
\hline PCA & Pseudomonas spp. & Pythium spp. & 9 species & $\begin{array}{l}\text { P. ultimum var. sporangiiferum has the lowest } \\
\text { sensitivity. }\end{array}$ & Gurusiddaiah et al. (1986) \\
\hline Kanosamine & Bacillus cereus & Pythium spp. & 3 species & $\begin{array}{l}\text { P. aphanidermatum and P. torulosum are less } \\
\text { sensitive. }\end{array}$ & Milner et al. (1996) \\
\hline $\begin{array}{l}\text { Lipopeptide } \\
\text { Massetolide } \\
\text { A }\end{array}$ & $\begin{array}{l}\text { Pseudomonas } \\
\text { fluorescens SS101 }\end{array}$ & Pythium spp. & 8 species & $\begin{array}{l}\text { P. heterothallicum, P. rostratum, P. ultimum have a } \\
\text { greater tolerance. }\end{array}$ & Mazzola et al. (2007) \\
\hline Gliotoxin & Gliocladium virens & Rhizoctonia solani & 18 & $\begin{array}{l}\text { Some Anastomosis Groups less sensitive than } \\
\text { others. }\end{array}$ & Jones and Pettit (1987) \\
\hline Pyrrolnitrin & $\begin{array}{l}\text { Pseudomonas } \\
\text { chlororaphis }\end{array}$ & Botrytis cinerea & 204 & $\begin{array}{l}\text { Diverse levels of sensitivity ( } \mathrm{RF}=8.4 \text { for the most } \\
\text { resistant isolates); isolates controlled by the BCA } \\
\text { on tomato stem. }\end{array}$ & Ajouz et al. (2011b) \\
\hline
\end{tabular}

${ }^{1}$ Antimicrobial compounds produced by biocontrol agents: 2,4-DAPG, 2,4-diacetylphloroglucinol; PCA, phenazine-1-carboxylic acid. ${ }^{2}$ BCA, biocontrol agent. ${ }^{3}$ RF, resistance factor.

results raised the question of whether this pre-existing moderate level of resistance could foster the acquisition of a higher level of resistance to pyrrolnitrin through selective pressure, should the use of pyrrolnitrin-producing biocontrol agents become widespread in the field.

This diversity of sensitivity to antimicrobial compounds produced by biocontrol agents was also observed among different anastomosis groups within a species or different species of plant pathogens that could occur and can infect plants at the same time. For instance, variation in sensitivity among 18 isolates of Rhizoctonia solani to the antibiotic gliotoxin (produced by the biocontrol fungus Gliocladium virens) was observed, with isolates of some anastomosis groups being less sensitive than others (Jones and Pettit, 1987). This was also the case for individual isolates of several closely related species of Pythium, commonly found together in symptoms developed by this complex of soilborne oomycetes. Differences of sensitivity among species of this complex were reported for PCA, P. ultimum var. sporangiferum being the least sensitive (Gurusiddaiah et al., 1986), for kanosamine (an antibiotic synthesized by the bacterium Bacillus cereus), $P$. medicaginis being less sensitive than $P$. aphanidermatum and P. torulosum (Milner et al., 1996), for the cyclic lipopeptide massetolide, $P$. heterothallicum, $P$. rostratum, and $P$. ultimum var. ultimum being the least sensitive of eight Pythium species (Mazzola et al., 2007), and for 2,4-DAPG, P. volutum being the most sensitive and $P$. deliense the least sensitive of 13 species (De Souza et al., 2003). One striking aspect of this latter study is that various types of asexual propagules of P. ultimum var. sporangiiferum (mycelium, zoosporangia, zoospore cysts, and zoospores) differed considerably in their sensitivity to 2,4-DAPG. The difference of susceptibility among Pythium species to various natural toxic compounds produced by biocontrol agents and the fact that several of these species could occur at the same time in a similar specific place may impact the success or at least the regularity of the effectiveness of biological control conferred by these antibiotic-producing bacterial strains.

\section{Variation in Sensitivity of Plant Pathogens to Biocontrol Agents or Plant Extracts Having a Single Mode of Action}

Several studies have been conducted on the antibiotic-producing biocontrol agents themselves, and not only on the antimicrobial compounds involved in their effectiveness (Table 3). A well documented case concerns the control of bacterial plant pathogen Agrobacterium tumefaciens, the causal agent of crown gall on many dicotyledonous plants, by biocontrol agent $A$. rhizogenes strain K84, which produces the antibiotic agrocin 84 (Moore and Warren, 1979). Among 65 strains of A. tumefaciens, all those belonging to biotype three were resistant to the biocontrol agent in vitro, whereas many of biotype 1 and biotype 2 strains were susceptible (VAN Zyl et al., 1986).

Variability was also observed with biological control of potato scab, caused by Streptomyces scabies. Otto-Hanson et al. 
TABLE 3 | Examples highlighting the variation in sensitivity of plant pathogens to biological control agents or plant extracts described as having a simple mode of action.

\begin{tabular}{|c|c|c|c|c|c|}
\hline $\begin{array}{l}\text { Modes of } \\
\text { action of BCA }\end{array}$ & BCA/plant extract & Plant pathogen & $\begin{array}{l}\text { Number of } \\
\text { isolates }\end{array}$ & Main results & Reference \\
\hline \multirow[t]{8}{*}{ Antibiosis } & $\begin{array}{l}\text { Agrobacterium } \\
\text { rhizogenes }\end{array}$ & $\begin{array}{l}\text { Agrobacterium } \\
\text { tumefaciens }\end{array}$ & 65 & $\begin{array}{l}\text { Biotype } 3 \text { are resistant to the antibiotic } \\
\text { agrocin } 84 .\end{array}$ & VAN Zyl et al. (1986) \\
\hline & $\begin{array}{l}\text { B. subtilis, Serratia } \\
\text { plymuthica, P. putida, } \\
\text { Streptomyces setonii }\end{array}$ & Rhizoctonia solani & 8 & $\begin{array}{l}\text { Diverse levels of sensitivity (dual culture } \\
\text { assay in vitro). }\end{array}$ & Faltin et al. (2004) \\
\hline & Bacillus mojavensis & Fusarium verticillioides & 3 & $\begin{array}{l}\text { Diversity in percent of lesion reduction } \\
\text { in maize. }\end{array}$ & Bacon and Hinton (2011) \\
\hline & $\begin{array}{l}4 \text { endophytes of } \\
\text { elm }+2 \text { Trichoderma } \\
\text { strains }\end{array}$ & Ophiostoma novo-ulmi & 6 & $\begin{array}{l}\text { In vitro growth inhibition less marked in } \\
\text { some strains of } O \text {. novo-ulmi. }\end{array}$ & Diaz et al. (2013) \\
\hline & $\begin{array}{l}15 \text { fungal endophyte } \\
\text { species }\end{array}$ & Gremmeniella abietina & 4 & $\begin{array}{l}\text { Diverse levels of sensitivity (dual culture } \\
\text { assay in vitro). }\end{array}$ & Santamaria et al. (2007) \\
\hline & $\begin{array}{l}20 \text { strains of } \\
\text { Streptomyces spp. }\end{array}$ & Streptomyces scabies & 15 & $\begin{array}{l}\text { Diverse levels of sensitivity; } 1 \text { isolate } \\
\text { resistant to } 16 \text { BCA strains. }\end{array}$ & Otto-Hanson et al. (2013) \\
\hline & $\begin{array}{l}3 \text { strains of } \\
\text { Streptomyces spp. }\end{array}$ & Botrytis cinerea & 41 & $\begin{array}{l}\text { In vitro growth inhibition less marked in } \\
\text { some strains of } B \text {. cinerea. }\end{array}$ & Boukaew et al. (2015) \\
\hline & $\begin{array}{l}\text { Aqueous extract of } \\
\text { Cuscuta pedicellata L. }\end{array}$ & Xanthomonas campestris & $\begin{array}{l}\text { different } \\
\text { pathovars }\end{array}$ & $\begin{array}{l}\text { In vitro variation in susceptibility among } \\
\text { pathovars of } X \text {. campestris. }\end{array}$ & Ali et al. (2013) \\
\hline \multirow[t]{5}{*}{ Hyperparasitism } & $\begin{array}{l}\text { Cryphonectria } \\
\text { hypovirus } 1(\mathrm{CHV}-1)\end{array}$ & Cryphonectria parasitica & 68 & $\begin{array}{l}\text { Difference in tolerance; small magnitude } \\
\text { of tolerance. }\end{array}$ & $\begin{array}{l}\text { Peever et al. (2000), Bryner } \\
\text { and Rigling (2012) }\end{array}$ \\
\hline & 5 bacteriophages & Erwinia amylovora & 52 & $\begin{array}{l}23 \text { strains exhibit resistance to at least } \\
\text { one phage. }\end{array}$ & $\begin{array}{l}\text { Schnabel and Jones } \\
(2001)\end{array}$ \\
\hline & Acremonium strictum & Helminthosporium solani & 4 & Diverse levels of sensitivity. & Rivera-Varas et al. (2007) \\
\hline & Coniothyrium minitans & $\begin{array}{l}\text { Sclerotinia sclerotiorum S. } \\
\text { trifoliorum }\end{array}$ & 349 & $\begin{array}{l}\text { Considerable variation in the rate and } \\
\text { extend of infection by Coniothyrium. }\end{array}$ & Turner and Tribe (1976) \\
\hline & Coniothyrium minitans & Sclerotinia sclerotiorum & 3 & 1 strains less susceptible to infection. & Huang et al. (2011) \\
\hline
\end{tabular}

(2013) reported that in vitro growth inhibition of S. scabies, using antibiotic-producing isolates of Streptomyces sp., varied depending on the isolates of the plant pathogen. Using 15 isolates of S. scabies and 19 antagonistic strains of Streptomyces $\mathrm{sp}$, they showed that there was significant variation among pathogen isolates in their susceptibility to inhibition, and one isolate exhibited low susceptibility and was inhibited by only four of the antagonistic strains. This illustrated that there was a high level of diversity both among the isolates of the pathogen and among the antagonists. Interestingly, only one of the 19 antagonistic isolates was able to inhibit the growth of all 15 isolates of $S$. scabies. In the same vein, using a dual-in vitro culture technique, Boukaew et al. (2015) observed that among 41 strains of $B$. cinerea, only 31,31 , and 25 were completely inhibited by strains RM-1-138, RL-1-178, and SS-2-243 of Streptomyces spp., respectively.

Some level of variability in the sensitivity to biocontrol agents has also been encountered in other studies involving fewer strains of plant pathogens. This was the case for example, among eight isolates of Rhizoctonia solani examinated for their sensitivity to antibiotic-producing bacterial strains of Bacillus subtilis, Serratia plymuthica, Pseudomonas putida, and Streptomyces setonii (Faltin et al., 2004) and among six strains of Ophiostoma novo-ulmi evaluated for their sensitivity to four endophytic fungi of elm and two Trichoderma strains (Diaz et al., 2013). Finally, the in vitro susceptibility of Xanthomonas campestris to aqueous extracts of the plant species Cuscuta pedicellata was shown to vary according to the pathovar of the bacterium (Ali et al., 2013).
All these examples clearly highlight the challenge one may face for the development of a single-strain biocontrol agent with wide effectiveness against diverse populations of plant pathogens.

\section{Variation in Sensitivity of Plant Pathogens to Hyperparasites}

Several studies have explored the diversity of sensitivity to hyperparasitic biocontrol agents (Table 3). The best documented cases involve viral (hyper)parasites of plant pathogens. One success story of biological control against plant diseases concerns the Cryphonectria hypovirus $1(\mathrm{CHV}-1)$ that hyperparasitizes the fungus Cryphonectria parasitica and reduces its pathogenicity on chestnut trees, resulting in hypovirulent isolates of the fungus (Milgroom and Cortesi, 2004). Infection with CHV-1 is persistent and does not kill C. parasitica. However, it inhibits its sexual reproduction and strongly attenuates the growth and conidial sporulation of the fungus. The resulting hypovirulence provides adequate control of chesnut blight in Europe and in some locations in the United States, with the exception of eastern North America. Differences in tolerance to $\mathrm{CHV}-1$ in different populations of $C$. parasitica were detected (Peever et al., 2000; Bryner and Rigling, 2012). Even thought the magnitude of tolerance to the hypovirus is relatively small, these results suggest that there is a potential for future evolution of this character in the natural populations of the plant pathogenic fungus. Evidence that different strains of bacteria can present a diversity of sensitivity to bacteriophages was also proposed. In order to control fire blight caused by 
TABLE 4 | Examples highlighting the variation in sensitivity of plant pathogens to biological control agents or plant extracts having several modes of action.

\begin{tabular}{|c|c|c|c|c|c|}
\hline Mode of action* & BCA/plant extract & Plant pathogen & $\begin{array}{l}\text { Number of } \\
\text { isolates }\end{array}$ & Main results & Reference \\
\hline Antibiosis + competition & $\begin{array}{l}\text { Rhodotorula glutinis } \\
\text { PM4 }\end{array}$ & Botrytis cinerea & 29 & $\begin{array}{l}\text { Variable susceptibility; some isolates } \\
\text { totally resistant; no correlation with } \\
\text { aggressiveness of } B \text {. cinerea. }\end{array}$ & Buck and Jeffers (2004) \\
\hline Antibiosis + CWDE + IR & $\begin{array}{l}\text { Bacillus subtilis } \\
\text { QST713 }\end{array}$ & Botrytis cinerea & 20 & $\begin{array}{l}\text { Wide range of sensitivity; differences } \\
\text { of efficacy between tomato and } \\
\text { lettuce leaves; no correlation with } \\
\text { aggressiveness of } B \text {. cinerea. }\end{array}$ & Bardin et al. (2013a) \\
\hline \multirow[t]{4}{*}{ Direct effect $+\mathbb{I R}$} & $\begin{array}{l}\text { Plant extract from } \\
\text { rhubarb }\end{array}$ & Podosphaera xanthii & 162 & Limited amount of diversity. & Yang et al. (2008) \\
\hline & $\begin{array}{l}\text { Plant extract from } \\
\text { rhubarb }\end{array}$ & $\begin{array}{l}\text { Pseudoperonospora } \\
\text { cubensis }\end{array}$ & 116 & Limited amount of diversity. & Yang et al. (2008) \\
\hline & $\begin{array}{l}\text { Plant extract from } \\
\text { giant knotweed }\end{array}$ & Podosphaera xanthii & 52 & $\begin{array}{l}\text { Wide range of sensitivity, some } \\
\text { isolates able to sporulate. }\end{array}$ & Bardin et al. (2013c) \\
\hline & $\begin{array}{l}\text { Plant extract from } \\
\text { giant knotweed }\end{array}$ & $\begin{array}{l}\text { Golovinomyces } \\
\text { cichoracearum }\end{array}$ & 5 & $\begin{array}{l}\text { Wide range of sensitivity, some } \\
\text { isolates able to sporulate. }\end{array}$ & Bardin et al. (2013c) \\
\hline Complex mode of action & $\begin{array}{l}\text { Trichoderma } \\
\text { harzianum strain T22 }\end{array}$ & Calonectria pauciramosa & 20 & $\begin{array}{l}\text { Ability to product microsclerotia and } \\
\text { effect in controlling infection highly } \\
\text { variable among isolates of } C \text {. } \\
\text { pauciramosa. }\end{array}$ & Vitale et al. (2012) \\
\hline $\begin{array}{l}\text { Competition }+ \text { other } \\
\text { indirect effects? }\end{array}$ & $\begin{array}{l}\text { Microdochium } \\
\text { dimerum }\end{array}$ & Botrytis cinerea & 41 & $\begin{array}{l}\text { High level of efficacy at } \\
\text { recommended dose; Variable } \\
\text { susceptibility at low dose: } \\
\text { correlation of protection and } \\
\text { aggressiveness of } B \text {. cinerea. }\end{array}$ & Bardin et al. (2013b) \\
\hline
\end{tabular}

${ }^{*} / R$, induced plant resistance; competition, competition for nutrient; CWDE, cell-wall degrading enzyme.

the bacterium Erwinia amylovora, bacteriophages were tested as biocontrol agents (Schnabel and Jones, 2001). The ability of five phages to infect 52 strains of E. amylovora varied dramatically. Only 22 of 52 strains were sensitive to all five phages, and 23 strains exhibited resistance to more than one phage.

Other studies concern fungal hyperparasites. Coniothyrium minitans is a hyperparasite of sclerotia produced by various pathogenic fungal species including Sclerotinia spp. (Gerlagh et al., 1996; Whipps et al., 2008). The susceptibility of Sclerotinia spp. to C. minitans was evaluated on 34 strains of S. sclerotiorum and nine strains of $S$. trifoliorum, revealing considerable variation in the rate and extend of sclerotial infection by the mycoparasite (Turner and Tribe, 1976). More recently, Huang et al. (2011) suggested that reduced susceptibility to sclerotial infection by $C$. minitans may be related to the production of oxalate by strains of S. sclerotiorum. Diversity in susceptibility was also observed for four strains of the plant pathogenic fungus Helminthosporium solani to the mycoparasite Acremonium strictum, with ranges of in vitro inhibition of $35-65 \%, 43-53 \%$, and $32-40 \%$, for sporulation, spore germination and mycelial growth of the plant pathogen, respectively (Rivera-Varas et al., 2007).

\section{Variation in Sensitivity of Plant Pathogens to Biocontrol Agents or Plant Extracts Combining Several Modes of Action}

For many biocontrol agents, several modes of action have been identified and are believed to play a role in their protective effect against plant pathogens. A few studies have examined their efficacy toward different isolates of plant pathogens and revealed some level of variability (Table 4).

For microbial biocontrol agents, this is the case for instance for the yeast Rhodotorula glutinis PM4, which was reported to inhibit $B$. cinerea both by competing for nutrients and by producing the toxic compound rhodotorulic acid (Sansone et al., 2005). In a study comparing 29 isolates of $B$. cinerea a wide range of susceptibility to the effect of the biocontrol agent was encountered, with several isolates showing complete resistance and producing symptoms (Buck and Jeffers, 2004). No obvious correlation between the relative aggressiveness of $B$. cinerea and the effectiveness of $R$. glutinis PM4 was observed. B. cinerea was also reported to display a wide range of susceptibility toward the protective effect of other beneficial microbes. One is Bacillus subtilis QST713, a biocontrol agent presumed to operate through various modes of action such as antibiosis, competition, hyperparasitism, and induction of resistance (Paulitz and Belanger, 2001; Lahlali et al., 2013). In a study comparing 20 strains of $B$. cinerea (differing in their geographic origin, host of isolation and level of aggressiveness), the protective efficacy of $B$. subtilis QST713 was found to range from 40 to $86 \%$ on tomato leaves and from 0 to $80 \%$ on lettuce leaves (Bardin et al., 2013a). Another study concerns strain L13 of Fusarium sp., which was shown to protect pruning wounds of tomato against $B$. cinerea (Bardin et al., 2008). A very high level of efficacy was observed against 41 isolates of $B$. cinerea when the biocontrol agent was used at the recommended dose of $10^{7}$ spores $/ \mathrm{ml}$ (Bardin et al., 2013b). However, at a 10-fold reduced dose of application the diversity of sensitivity of $B$. cinerea to this biocontrol agent was 
high. A correlation was noticed between the level of aggressiveness of $B$. cinerea and the level of protection provided by the biocontrol agent (Bardin et al., 2013b). This correlation is probably the consequence of the presumed mode of action of this biocontrol agent, which is not based on a direct effect but more probably linked to a competition for nutrients and space. Other examples concern species of one of the most studied genera of microbial biocontrol agent, Trichoderma. The effect of Trichoderma species on plant pathogens have been shown to involve several modes of action (Elad, 2000; Howell, 2003; Harman, 2006). In a study involving strain T22 of T. harzianum, Vitale et al. (2012) observed that its protective effect was highly variable among 20 isolates of the fungal plant pathogen Calonectria pauciramosa and that, in presence of the biocontrol agent, some isolates conserve the ability to produce about as much microsclerotia as the control without biocontrol agent.

Few studies have evaluated the diversity of susceptibility of plant pathogens to plant extracts having a complex mode of action (Table 4). One example is an extract from roots of Chinese rhubarb (Rheum officinale Baill.), which was shown to control powdery mildew of barley mainly through induced resistance and especially by enhancing expression of leaf-specific thionin in leaves (Ma et al., 2010). In a study to establish baselines of sensitivity for pathogens of cucumbers, tests on detached cotyledons with 162 isolates of Podosphaera xanthii (syn. Sphaerotheca fuliginea) and on leaf disks for 116 isolates of Pseudoperonospora cubensis revealed limited diversity among isolates of either species (Yang et al., 2008). Another example concerns leaf extracts of the giant knotweed Fallopia (Reynoutria) sachalinensis, whose mode of action is generally associated with plant-induced resistance (Daayf et al., 1997; Fofana et al., 2002), but which is also known to have a direct inhibitory effect on spore germination for different powdery mildew fungi, including Blumeria graminis (Randoux et al., 2006), Oidium neolycopersici, Leveillula taurica, or Golovinomyces cichoracearum (Table 5). A wide range of susceptibility was observed among 52 isolates of P. xanthii and five isolates of Golovinomyces cichoracearum on detached melon leaf disks treated with a commercial preparation of the extract (Bardin et al., 2013c). Sporulation by some isolates was observed on the leaf disks, suggesting that use of this plant extract on a commercial scale could possibly lead to the selection of resistant isolates.

Biocontrol agents with multiple modes of action are commonly considered as presenting no, or very limited risk for the

TABLE 5 | Effect of the formulated plant extract from Fallopia (Reynoutria) sachalinensis $\left(\right.$ Milsana $^{\circledR}$ ) applied at different concentrations on the spore germination of three different powdery mildew species on solid medium (10 g/L agar), $72 \mathrm{~h}$ after inoculation.

\begin{tabular}{|c|c|c|c|}
\hline \multirow{2}{*}{$\begin{array}{l}\text { Concentration of formulated } \\
\text { plant extract }\end{array}$} & \multicolumn{3}{|c|}{ Spore germination rate (\%) } \\
\hline & Control & $2.5 \mathrm{~mL} / \mathrm{L}$ & $2500 \mathrm{~mL} / \mathrm{L}$ \\
\hline Oidium neolycopersici & $81 \pm 9$ & $9 \pm 1$ & 0 \\
\hline Leveillula taurica & $60 \pm 8$ & $13 \pm 2$ & 0 \\
\hline Golovinomyces cichoracearum & $60 \pm 9$ & $42 \pm 9$ & 0 \\
\hline
\end{tabular}

Results are the mean of three independent experiments. Each mean is associated with its standard error. development of resistance by plant pathogens. Although the number of studies on this topic is still scant, this concept may be need to considered with caution as the examples shown above clearly demonstrate that plant pathogens can display a high level of diversity in their sensitivity to such biocontrol agents.

\section{Capacity of Plant Pathogens to Adapt to Biological Control}

Besides existing diversity in susceptibility of plant pathogens to biocontrol agents, another concern could be that resistance would develop through adaptation under selection pressure, following the generalized use of a biological control method in the field, as has already occurred for various pathogens with certain fungicides. The estimation of this potential risk can be achieved through experimental evolution studies with the production of successive generations of the pathogens under selection pressure, as commonly carried out to evaluate the durability of efficacy of antimicrobial compounds in human pathology (Cowen et al., 2002), or to assess the capacity of plant pathogens to adapt to fungicides (Brent and Hollomon, 1998). One of the very few studies of this type conducted on biocontrol agents of plant diseases was carried out with Bacillus subtilis CL27, a bacterium producing three different antifungal compounds, two of which were effective in vitro against B. cinerea (Li and Leifert, 1994; Leifert et al., 1995). Following eight successive treatments on plants of Astilbe hybrida, the protective effect of the biocontrol agent against $B$. cinerea strongly decreased and control became totally ineffective after the 10th treatment (Li and Leifert, 1994). In another experimental evolution study, Ajouz et al. (2010) observed the acquisition of resistance by five isolates of $B$. cinerea to pyrrolnitrin. This buildup of resistance was correlated in vitro with a reduced inhibitory effect of the pyrrolnitrin-producing biocontrol strain ChPhzS24 of P. chlororaphis. For all isolates of $B$. cinerea, the adaptation was observed after 12 successive generations produced under selection pressure in vitro. The first 10 generations were grown on nutrient medium containing a concentration of pyrrolnitrin of $10 \mu \mathrm{g} / \mathrm{L}$, which corresponded to an inhibition of mycelial growth comprised between 56 and $98 \%$ depending on the isolates. For these 10 generations, no major change in sensitivity to pyrrolnitrin was observed. In contrast, the production of additional generations on media containing higher doses of pyrrolnitrin resulted in the rapid development of variants with a high level of resistance to the antibiotic ( $\mathrm{RF}>1000)$. The same results were observed for all five strains of $B$. cinerea, regardless of their initial phenotype of sensitivity to the antibiotic (Ajouz et al., 2010). Interestingly, a similar experiment conducted with the same strains of $B$. cinerea on media containing the fungicide iprodione also led to buildup of resistance to iprodione and to pyrrolnitrin and to the pyrrolnitrin-producing biocontrol agent (Fillinger et al., 2012), suggesting that the use of chemical methods in parallel or in combination with biological control may have an impact on the durability of the efficacy of certain biocontrol agents.

In contrast to the situation with $B$. cinerea, no build up of resistance was observed after 15 generations for two biotrophic 
fungi (the powdery mildew fungus $P$. xanthii and the downy mildew oomycete $P$. cubensis) in an experimental evolution study on melon leaves treated with an extract from roots of Chinese rhubarb (Yang et al., 2008). This absence of evolution might be due to a complex mode of action of the plant extract, known to include both a direct antimicrobial effect and induced resistance (Ma et al., 2010). However, it would be interesting to assess if the production of additional generations of $P$. xanthii and $P$. cubensis on melon leaves treated with higher concentrations of the plant extract would result in the sudden build up of resistance as observed for B. cinerea by Ajouz et al. (2010). Interestingly, the high level of resistance to pyrrolnitrin attained by the last generations of $B$. cinerea in these experiments did not confer complete resistance to the effect of $P$. chlororaphis ChPhzS24 (Ajouz et al., 2010), a situation compatible with the report that other antibiotics, in addition to pyrrolnitrin, are produced by this strain (Schoonbeek et al., 2002). Finally, the buildup of resistance to pyrrolnitrin was associated with an important fitness cost for $B$. cinerea, with a significant reduction in mycelial growth, sporulation and ability to colonize plant tissues observed for the five isolates under study (Ajouz et al., 2010, 2011a).

To our knowledge, the three experimental evolution studies described here are the only examples illustrating the potential of plant pathogens to adapt to the effect of biocontrol agents. In two of these studies, the fungal pathogen ( $B$. cinerea) was able to rapidly adapt to the effect of the antibiotic-producing biocontrol agents tested. However, in the case of the pyrrolnitrinproducing biocontrol agent, a detrimental effect for the plant pathogen of the resistance to pyrrolnitrin would limit the risk of complete loss of efficacy. Based on the study with physcion, it is likely that this plant extract will have a low to moderate risk for resistance development of powdery mildew and downy mildew of cucurbits. Additional studies with other biocontrol agents having different modes of action would be necessary to infer a possible link between the durability of efficacy of a biocontrol agent and its mode of action. Similarly, additional studies with other plant pathogens would allow to generate hypotheses about a possible link between the durability of biological control and specific traits related to the plant pathogen.

\section{Mechanisms Potentially Involved in the Resistance to Biocontrol Agents}

Although only few studies have addressed the existence of resistance toward biocontrol agents among differents isolates of plant pathogens, mechanisms of resistance to toxic compounds produced by microorganisms or plants have been widely studied and extensively reviewed by several authors (Duffy et al., 2003; Raaijmakers et al., 2009). In this chapter we will present the main mechanisms of resistance of plant pathogens to potentially toxic compounds that can be directly or indirectly involved in the mechanisms of action of biocontrol agents (antibiosis, induced plant resistance, hyperparasitism). We will also present some studies that concern the tolerance of plant pathogens to nutritive stress which correspond to the mode of action of competition for nutrients.

\section{Resistance to Compounds Produced by Micro-Organisms}

Antimicrobial compounds play a major role in the suppression of plant pathogens by antagonistic microorganisms, especially in the soil (Raaijmakers et al., 2002). Plant pathogenic fungi, oomycetes and bacteria have developed a range of strategies to tolerate or resist the deleterious effects of such compounds. These strategies involve mechanisms such as active efflux, degradation of antimicrobial compounds, and interference with the regulation and biosynthesis of antimicrobial metabolites produced by antagonistic microorganisms (reviewed in Duffy et al., 2003).

\section{Excretion}

As a first line of defense against toxic compounds, microbes possess ABC (ATP-binding cassette), or MSF (major facilitator superfamily) transporters. These membrane proteins are able to transport a wide range of compounds and can evacuate outside of the cells diverse toxic metabolites. The tolerance conferred by these transporters is quite low but it is significant because it provides time for pathogens to activate some mechanisms of detoxification (Schouten et al., 2008). ABC transporters are more often involved in the protection of fungi against antifungal compounds than MSF transporters are (De Waard et al., 2006). The role of efflux pumps has been implicated in the resistance of B. cinerea to antibiotic compounds produced by several potential biocontrol agents in the genus Pseudomonas (Schoonbeek et al., 2002). Several antibiotics such as phenazines (PCN) were shown to induce the expression of $B$ catrB, a gene coding for an $A B C$ transporter, providing the first demonstration of the role of $A B C$ transporters in microbial interactions, especially to protect a plant pathogen against an antibiotic produced by a biocontrol agent. $\mathrm{ABC}$ transporters have been shown to affect the sensitivity of fungi to various natural toxic metabolites and have been implicated in cases of multi-drug resistance (De Waard et al., 2006). Multidrug resistance (MDR) is emerging in the field among phytopathogenic fungi maintained under strong selection pressures and leads to the development of isolates resistant to fungicides belonging to different chemical families (Kretschmer et al., 2009). Ajouz et al. (2011b) observed that isolates of $B$. cinerea collected in the field and less sensitive to pyrrolnitrin were all multi-drug resistant isolates. In the plant pathogenic bacterium E. amylovora, a membrane transporter (NorM) was also shown to provide resistance to toxins produced by antagonistic bacteria P. fluorescens and Pantoea agglomerans (Burse et al., 2004). Therefore, these transporters could be a major mechanism of resistance to antibiotics-producing biocontrol agents that could be possibly combined with resistance to fungicides.

\section{Metabolization}

Other mechanisms have been involved in the resistance of plant pathogens to biocontrol agents acting through antibiosis. For example, exposure of Mycosphaerella graminicola to a sublethal dose of 1-hydroxyphenazine, an antibiotic produced by the biocontrol bacterium Pseudomonas, led to increased production by the fungus of catalases, peroxidases, and superoxidedismutases and an increase in melanin synthesis, allowing the 
degradation of the antibiotic and the protection of the fungus (Levy et al., 1992). In another study using the bacterium $P$. fluorescens, Rhizoctonia solani resulted in the synthesis by the fungus of laccases in response to the effects of bacterial metabolites (Crowe and Olsson, 2001). These laccases render fungal cell walls less permeable to toxic compounds and can detoxify antifungal compounds produced by the bacterium.

\section{Biosynthesis Inhibition}

Interference with the biosynthesis of antimicrobial compounds can also be a means for plant pathogens to be resistant to biocontrol agents. Fusaric acid, a toxin produced by the plant pathogenic fungus $F$. oxysporum, represses the production of the antimicrobial 2,4-DAPG within the biocontrol strain $P$. fluorescens CHA0 (Notz et al., 2002). This repressive effect may affect the performance of biocontrol bacteria that are sensitive to fusaric acid. A plant pathogen can also reduce the antibiotic production of a biocontrol agent, by altering its chemical environment. For example the plant pathogenic fungus Gaeumannomyces graminis var tritici acidifies the environment, thus disturbing the activity of the antagonistic bacterium $P$. fluorescens by significantly decreasing its effectiveness (Ownley et al., 1992).

Finally, natural plasmid transfer between bacteria was also shown to provide a possible mechanism for plant pathogens to become resistant to biocontrol agents. This was the case for example for the soilborne bacterium $A$. tumefaciens which became resistant to biocontrol agent $A$. radiobacter $\mathrm{K} 84$ by acquiring its plasmid pAgK84 (Stockwell et al., 1996). The resistance resulted from the fact that this plasmid carries both the gene coding for the production of agrocin 84 , the antibiotic responsible for the activity of the biocontrol agent, and the gene involved in the resistance to this antibiotic. It was suggested that the establishment of large populations of Agrobacterium carrying plasmid pAgK84 could threaten the effectiveness of $A$. radiobacter K84 as a biocontrol agent (Stockwell et al., 1996). To minimize the risk of transfer of this plasmid by A. tumefaciens, a derivative strain of K84 was constructed (K1026), that still produces agrocin 84 but lacks the region necessary for the transfer of the plasmid pAgK84. The judicious use of biocontrol agents and particularly of the new strain K1026 should minimize the risk of pAgK84 transfer into pathogenic Agrobacterium strains and thus help to preserve the effectiveness of $A$. radiobacter as a biocontrol agent against crown gall.

\section{Resistance to Cell Wall Degrading Enzymes Produced by Biocontrol Agents}

Most biocontrol agents acting by hyperparasitism produce enzymes such as chitinases and glucanases. Specific mechanisms can help plant pathogens to protect themselves against these cell wall degrading enzymes. For example, the synthesis of melanin polymers could help microorganisms to protect against microbial enzymes (Bell and Wheeler, 1986). The formation of chlamydospore-like structures and vacuolated portions in mycelium allows the pigeonpea wilt pathogen Fusarium udum to maintain a slow growth and the production of conidia in presence of the hyperparasitic bacterium Bacillus subtilis AF1 (Harish et al., 1998). Another possible mechanism implies the repression of the synthesis of enzymes produced by the biocontrol agent. For instance, the mycotoxin DON, produced by Fusarium culmorum and Fusarium graminearum represses the expression of genes coding for chitinases in the biocontrol strain Trichoderma atroviride P1 (Lutz et al., 2003).

\section{Resistance to Defense Compounds Produced by the Plants}

The induction of resistance in plants involves the synthesis and the activation of plant defense compounds as the result of activity of an elicitor. This induction leads to rapid production of reactive oxygen species, modifications of cuticle thickness, cell wall appositions, accumulation of phenolic compounds and production of phytoalexins and pathogenesis-related proteins rendering the plants more resistance to pathogen attack (Wiesel et al., 2014). To survive and become established in a resistance-induced plant, plant pathogens have to overcome these induced host defense chemicals. Plant pathogens may evolve a combination of strategies to colonize and survive in this environment. Such strategies could include transporting toxic chemicals out of the cell or sequestrating them in cellular organelles, detoxifying host defense compounds by converting or modifying them and interfering with host signaling (Morrissey and Osbourn, 1999).

\section{Excretion}

A way for plant pathogens to cope with host defense chemicals is to secrete them out of the cells as in the case of antimicrobial compounds produced by biocontrol agents (see section above). For example, $\mathrm{ABC}$ transporter activity has been implicated in the tolerance of Nectria haematococca to pisatin, a phytoalexine of Pisum sativum (Denny et al., 1987), of B. cinerea to resveratrol, a phytoalexin of grape (Schoonbeek et al., 2001) and of Gibberella pulicaris to rishitin, a trait that is required for virulence of the fungus on potato tubers (Fleissner et al., 2002). Similarly, a recent study on Grosmannia clavigera, a fungal pathogen of pine trees, showed that this fungus can survive and become established in pine tissues by the induced expression of an efflux $A B C$ transporter GcABC-G1 (Wang et al., 2013). This allows the fungus to cope with intracellular levels of monoterpenes, which are among the most abundant antimicrobial pine defense chemicals. $\mathrm{ABC}$ transporters are potentially involved in the virulence and aggressiveness of fungal plant pathogens, by decreasing the toxic effect of phytoalexins (Del Sorbo et al., 2000).

\section{Metabolization}

Botrytis cinerea is for instance able to detoxify the alpha-tomatine, a phytoanticipin found in tomato plants (Quidde et al., 1998). In this study, 12 out of 13 isolates of $B$. cinerea tested are able to degrade alpha-tomatine thanks to a xylase activity that prevents the saponin from complexing with the fungus membrane and therefore suppresses its antifungal activity. The ability of $B$. cinerea to overcome the phytoalexin resveratrol, which synthesis is induced in grapevine, has also been observed (Sbaghi et al., 
1996). A correlation between the ability of eight isolates of $B$. cinerea to detoxify the resveratrol and their pathogenicity on grapevine leaves was shown. Some plant pathogens, like the fungus Microcyclus ulei, are tolerant to hydrocyanic acid, a volatile compound produced by plants in response to various damages (Osbourn, 1996). This tolerance might be due to cyanide-resistant respiration. Other fungi could also detoxify this compound by converting it to formamide, via cyanide-hydratases. Some plant pathogens are then able to degrade defense compounds and thus might be able to overcome the effect of biocontrol agents acting through plant defense induction.

\section{Protection Against Oxidative Damage}

The hypersensitive reaction (HR) involves the production of reactive oxygen species that leads to cell death and it is generally consider as a signal to induce the synthesis of antimicrobial compounds like phytoalexins. It usually prevents the fungal penetration into host tissue but it has been shown that HR facilitates the colonization of the plants by necrotroph fungal pathogens like B. cinerea or S. sclerotiorum (Govrin and Levine, 2000; Govrin et al., 2006) or Rhizoctonia solani (Shibu et al., 2012). These plant pathogenic fungi might therefore exploit particular defense mechanisms of the plant to overcome the induced resistance effect of a biocontrol agent. Moreover, many other plant pathogens can protect themselves against oxidative damage (Duffy et al., 2003).

\section{Reducing Populations of Biocontrol Agents}

Some plant pathogens can significantly slow down the growth of biocontrol agents by exploiting more rapidly the resources within their environment and then affecting their efficacy. This was shown in a study conducted to evaluate the effect of several fungal root pathogens on the capacity of biocontrol strains $P$. fluorescens 2-79 and Q72a80 to persist in the wheat rhizosphere (Mazzola and Cook, 1991). For instance, in presence of some Pythium species, the population of $P$. fluorescens declines. In this case, the infection by Pythium tends to reduce the root surface available for bacterial colonization which, as a consequence, tends to limit the population of potential antagonists. In another study, the plant pathogenic oomycete $P$. ultimum can affect the genes expression of the biocontrol agent P. fluorescens F113, leading to the decline of its population (Fedi et al., 1997). This population size reduction limits the competition in the rhizosphere for nutrients leaking from wounds caused by $P$. ultimum on sugar beet roots. Competition may also occur on the phyllosphere where the microbial community is also important in number and diversity and where microorganism-microorganism interactions can occur (Vorholt, 2012). This microbial community may also affect the efficacy of biocontrol agents. Knowledge about plant microbiome (rhizosphere, phyllosphere, endosphere) and the microbial interactions occurring on those niches should contribute to the improvement of biological control.

\section{Conclusion}

Despite the limited number of published studies dedicated to this topic, it is clear from this review that plant pathogens can display various (including very low) levels of sensitivity to biocontrol agents, regardless of the complexity of their mode of action. Certain pathogens also have the potential to adapt in a few generation to the selection pressure exerted by biocontrol agents. Available information is sufficient to suggest that the assumption that durability of biological control is necessarily higher than that of chemical control may not always be justified. However, it is not sufficient to draw conclusions about the existence of specific traits related to the plant pathogen or related to the biocontrol agent that could explain the loss of effectiveness of a biocontrol agent in practice.

There is much need for further studies on issues related to this topic. Among them, the establishment of baseline sensitivity (i.e., testing a sufficient number of samples of field populations of target plant pathogens for their degree of sensitivity to one or more biocontrol agents) would be helpful in future surveys of biocontrol agents. Such monitoring is carried out routinely for fungicide resistance in fungal plant pathogens world-wide (Brent and Hollomon, 2007). It is a first step to evaluate the distribution and the potential impact of resistance in the field. Moreover, detection of partially resistant isolates may indicate a risk of developing a more severe resistance that subsequently may initiate a possible loss of control in the field. Monitoring can be done at specific sites, for example to ascertain the implication of resistance in cases when loss of biocontrol effectiveness is observed in the field. It can also be done at different dates to document the evolution of sensitivity following series of treatments with a given biocontrol agent and to monitor possible shifts in the natural populations of a plant pathogen, as suggested by Yang et al. (2008). Finally, cross-resistance with other existing biocontrol agents (or possibly fungicides) may also be determined.

In addition to the population approach described above, experimental evolution studies are also needed to evaluate the ability of plant pathogens to evolve under the selection pressure exerted by a biocontrol agent. This approach will result in identifying risk factors that can foster the selection of strains of plant pathogens resistant to biocontrol agents. Various biocontrol agents and different plant pathogens must be tested in the future. This will result in identifying types of biocontrol agents with lower risk of efficacy loss, i.e., modes of action of biocontrol agents that does not favor the selection of resistant isolates in natural populations of plant pathogens. Even though all biocontrol agents should create selection pressure on target populations of plant pathogen, some modes of action may present a clear opportunity for pathogens to evolve resistance. For example, a mechanism involving antibiosis would, by analogy with the fungicides, be considered a high risk to be overcome, whereas a multiple or a more complex mode of action would indicate relatively low risk. This knowledge is essential to ensure a durable efficacy of biocontrol agents on target plant pathogens.

Even if the data are too sparse to suggest general statement on the use of biocontrol agents in practice, this review highlights the necessity for careful management of their use once they become commercially available in order to avoid repeating the mistakes made with chemical fungicides. For instance, we should consider alternating or combining biocontrol agents with different mechanisms of action. In addition to possibly ensure 
the durability of biological control, the combination of several biocontrol agents have shown to improve the efficacy and reduce the variability of efficacy (Flaherty et al., 2000; Guetsky et al., 2001, 2002; de Boer et al., 2003). The context of integrated pest management is probably an effective way to reduce the risk of resistance development but it necessitates to evaluate the compatibility of the biocontrol agents together with other protection methods. The combined use of biocontrol agents together with pesticides requires that their efficiency is not altered when applied in conjunction or in alternation.

Significant research efforts are also needed to anticipate the potential failure of biological control and integrate durability concerns in the screening procedure of new biocontrol agents. According to the results mentioned in this review, caution should be applied when screening and selecting isolates of biocontrol agents, to ensure a wide representation of the targeted plant pathogen population. To test the efficacy of potential

\section{References}

Ajouz, S., Bardin, M., Nicot, P. C., and El Maataoui, M. (2011a). Comparison of the development in planta of a pyrrolnitrin-resistant mutant of Botrytis cinerea and its sensitive wild-type parent isolate. Eur. J. Plant Pathol. 129, 31-42. doi: 10.1007/s10658-010-9638-5

Ajouz, S., Walker, A. S., Fabre, F., Leroux, P., Nicot, P. C., and Bardin, M. (2011b). Variability of Botrytis cinerea sensitivity to pyrrolnitrin, an antibiotic produced by biological control agents. Biocontrol 56, 353-363. doi: 10.1007/s10526-0109333-7

Ajouz, S., Nicot, P. C., and Bardin, M. (2010). Adaptation to pyrrolnitrin in Botrytis cinerea and cost of resistance. Plant Pathol. 59, 556-566. doi: 10.1111/j.13653059.2009.02230.x

Alabouvette, C., Olivain, C., Migheli, Q., and Steinberg, C. (2009). Microbiological control of soil-borne phytopathogenic fungi with special emphasis on wiltinducing Fusarium oxysporum. New Phytol. 184, 529-544. doi: 10.1111/j.14698137.2009.03014.x

Ali, A., Haider, M. S., and Ashfaq, M. (2013). Biological control of fruit lesions caused by Xanthomonas campestris pathovars from Cuscuta pedicellata Ledeb. In vitro. J. Pure Appl. Microbiol. 7, 3149-3153.

Asser-Kaiser, S., Fritsch, E., Undorf-Spahn, K., Kienzle, J., Eberle, K. E., Gund, N. A., et al. (2007). Rapid emergence of baculovirus resistance in codling moth due to dominant, sex-linked inheritance. Science 317, 1916-1918. doi: 10.1126/science. 1146542

Bacon, C. W., and Hinton, D. M. (2011). In planta reduction of maize seedling stalk lesions by the bacterial endophyte Bacillus mojavensis. Can. J. Microbiol. 57, 485-492. doi: 10.1139/w11-031

Bardin, M., Comby, M., Lenaerts, R., and Nicot, P. C. (2013a). Diversity in susceptibility of Botrytis cinerea to biocontrol products inducing plant defence mechanisms. IOBC-WPRS Bull. 88, 45-49.

Bardin, M., Comby, M., Troulet, C., and Nicot, P. C. (2013b). Relationship between the aggressiveness of Botrytis cinerea on tomato and the efficacy of biocontrol. IOBC-WPRS Bull. 86, 163-168.

Bardin, M., Schmitt, A., and Nicot, P. C. (2013c). Diversity in the effect of an extract from Fallopia sachalinensis on isolates of cucurbit powdery mildews grown on melon. IOBC-WPRS Bull. 88, 93-97.

Bardin, M., Fargues, J., and Nicot, P. C. (2008). Compatibility between biopesticides used to control grey mould, powdery mildew and whitefly on tomato. Biol. Control 46, 476-483. doi: 10.1016/j.biocontrol.2008.05.012

Bell, J. A., and Wheeler, M. H. (1986). Biosynthesis and functions of fungal melanins. Annu. Rev. Phytopathol. 24, 411-451. doi: 10.1146 /annurev.py.24.090186.002211

Berling, M., Blachere-Lopez, C., Soubabere, O., Lery, X., Bonhomme, A., Sauphanor, B., et al. (2009). Cydia pomonella granulovirus genotypes overcome virus resistance in the codling moth and improve virus efficiency by selection against resistant hosts. Appl. Environ. Microbiol. 75, 925-930. doi: 10.1128/AEM.01998-08 biocontrol agents or to screen for new biocontrol agents against plant diseases, most studies continue to use a single isolate or relatively few isolates. Innovative screening procedures based on the known mode of action have already been developed (Schoonbeek et al., 2007; Sansone et al., 2011). We must go further by incorporating in the screening procedure, knowledge on the ability of plant pathogen to counteract these modes of action.

\section{Acknowledgments}

The research leading to these results has received funding from the European Union Seventh Framework Programme (FP7/2007-2013) under the grant agreement $n^{\circ} 265865$ (PURE project) and from the french Ministère de l'Agriculture de l'Agroalimentaire et de la Forêt (Recherche finalisé CASDAR, ScleroLeg Project $\left.{ }^{\circ} 1317\right)$.

Boukaew, S., Prasertsan, P., Petcharat, V., Troulet, C., and Bardin, M. (2015). Efficacy of Streptomyces spp. strains against different strains of Botrytis cinerea. IOPC-WPRS Bull. in press.

Brent, K. J., and Hollomon, D. W. (1998). "Fungicide resistance: the assessment of risk," in FRAC Monograph No. 2, (Brussels: Global Crop Protection Federation), $1-48$.

Brent, K. J., and Hollomon, D. W. (2007). Fungicide Resistance in Crop Pathogens: How Can it be Managed, 2nd Revised Edn. Brussels: CropLife International.

Bryner, S. F., and Rigling, D. (2012). Hypovirus virulence and vegetative incompatibility in populations of the chestnut blight fungus. Phytopathology 102, 1161-1167. doi: 10.1094/PHYTO-01-12-0013-R

Buck, J. W., and Jeffers, S. N. (2004). Effect of pathogen aggressiveness and vinclozolin on efficacy of Rhodotorula glutinis PM4 against Botrytis cinerea on geranium leaf disks and seedlings. Plant Dis. 88, 1262-1268. doi: 10.1094/PDIS.2004.88.11.1262

Burse, A., Weingart, H., and Ullrich, M. S. (2004). NorM, an Erwinia amylovora multidrug efflux pump involved in in vitro competition with other epiphytic bacteria. Appl. Environ. Microbiol. 70, 693-703. doi: 10.1128/AEM.70.2.693703.2004

Cowen, L. E., Anderson, J. B., and Kohn, L. M. (2002). Evolution of drug resistance in Candida albicans. Annu. Rev. Microbiol. 56, 139-165. doi: 10.1146/annurev.micro.56.012302.160907

Crowe, J. D., and Olsson, S. (2001). Induction of laccase activity in Rhizoctonia solani by antagonistic Pseudomonas fluorescens strains and a range of chemical treatments. Appl. Environ. Microbiol. 67, 2088-2094. doi: 10.1128/AEM.67.5.2088-2094.2001

Daayf, F., Schmitt, A., and Belanger, R. R. (1997). Evidence of phytoalexins in cucumber leaves infected with powdery mildew following treatment with leaf extracts of Reynoutria sachalinensis. Plant Physiol. 113, 719-727.

de Boer, M., Bom, P., Kindt, F., Keurentjes, J. J. B., van der Sluis, I., van Loon, L. C., et al. (2003). Control of Fusarium wilt of radish by combining Pseudomonas putida strains that have different disease-suppressive mechanisms. Phytopathology 93, 626-632. doi: 10.1094/PHYTO.2003.93.5.626

Del Sorbo, G., Schoonbeek, H. J., and De Waard, M. A. (2000). Fungal transporters involved in efflux of natural toxic compounds and fungicides. Fungal Genet. Biol. 30, 1-15. doi: 10.1006/fgbi.2000.1206

Denny, T. P., Matthews, P. S., and Etten, H. D. V. (1987). A possible mechanism of nondegradative tolerance of pisatin in Nectria haematococca MP VI. Physiol. Mol. Plant Pathol. 30, 93-107. doi: 10.1016/0885-5765(87)90085-3

De Souza, J. T., Arnould, C., Deulvot, C., Lemanceau, P., Gianinazzi-Pearson, V., and Raaijmakers, J. M. (2003). Effect of 2,4-diacetylphloroglucinol on Pythium: cellular responses and variation in sensitivity among propagules and species. Phytopathology 93, 966-975. doi: 10.1094/PHYTO.2003.93.8.966

De Waard, M. A., Andrade, A. C., Hayashi, K., Schoonbeek, H. J., Stergiopoulos, I., and Zwiers, L.-H. (2006). Impact of fungal drug transporters on fungicide sensitivity, multidrug resistance and virulence. Pest. Manag. Sci. 62, 195-207. doi: $10.1002 /$ ps. 1150 
Diaz, G., Córcoles, A. I., Asencio, A. D., and Torres, M. P. (2013). In vitro antagonism of Trichoderma and naturally occurring fungi from elms against Ophiostoma novo-ulmi. For. Pathol. 43, 51-58.

Duffy, B., Schouten, A., and Raaijmakers, J. M. (2003). Pathogen self-defense: mechanisms to counteract microbial antagonism. Annu. Rev. Phytopathol. 41, 501-538. doi: 10.1146/annurev.phyto.41.052002.095606

Eberle, K. E., and Jehle, J. A. (2006). Field resistance of codling moth against Cydia pomonella granulovirus (CpGV) is autosomal and incompletely dominant inherited. J. Invertebr. Pathol. 93, 201-206. doi: 10.1016/j.jip.2006.07.001

Elad, Y. (2000). Biological control of foliar pathogens by means of Trichoderma harzianum and potential modes of action. Crop Prot. 19, 709-714. doi: 10.1016/S0261-2194(00)00094-6

Elad, Y., and Stewart, A. (2004). "Microbial control of Botrytis spp.," in Botrytis: Biology, Pathology and Control. Dordrecht, eds Y. Elad B. Williamson, P. Tudzynski, and N. Delen (Dordrecht: Kluwer Academic Press), 223-241.

Faltin, F., Lottmann, J., Grosch, R., and Berg, G. (2004). Strategy to select and assess antagonistic bacteria for biological control of Rhizoctonia solani Kühn. Can. J. Microbiol. 50, 811-820. doi: 10.1139/w04-063

Fedi, S., Tola, E., Moenne-Loccoz, Y., Dowling, D. N., Smith, L. M., and O'Gara, F. (1997). Evidence for signalling between the phytopathogenic fungus Pythium ultimum and Pseudomonas fluorescens F113: P. ultimum represses the expression of genes in P. fluorescens F113, resulting in altered ecological fitness. Appl. Environ. Microbiol. 63, 4261-4266.

Fillinger, S., Ajouz, S., Nicot, P. C., Leroux, P., and Bardin, M. (2012). Functional and structural comparison of pyrrolnitrin- and iprodione-induced modifications in the class III histidine-kinase Bos1 of Botrytis cinerea. PLoS ONE 7:e42520. doi: 10.1371/journal.pone. 0042520

Flaherty, J. E., Somodi, G. C., Jones, J. B., Harbaugh, B. K., and Jackson, L. E. (2000). Control of bacterial spot on tomato in the greenhouse and field with h-mutant bacteriophages. HortScience 35, 882-884.

Fleissner, A., Sopalla, C., and Weltring, K. M. (2002). An ATP-binding cassette multidrug-resistance transporter is necessary for tolerance of Gibberella pulicaris to phytoalexins and virulence on potato tubers. Mol. Plant Microbe Interact. 15, 102-108. doi: 10.1094/MPMI.2002.15.2.102

Fofana, B., Mcnally, D. J., Labbé, C., Boulanger, R., Benhamou, N., Séguin, A., et al. (2002). Milsana-induced resistance in powdery mildew-infected cucumber plants correlates with the induction of chalcone synthase and chalcone isomerase. Physiol. Mol. Plant Pathol. 61, 121-132. doi: 10.1016/S08855765(02) $90420-0$

Fritsch, E., Undorf-Spahn, K., Kienzle, J., Zebitz, C., and Hüber, J. (2005). Apfelwickler-Granulovirus: Erste Hinweise auf Unterschiede in der Empfindlichkeit lokaler Apfelwickler-Populationen (Codling moth granulovirus: first indication of variations in the susceptibility of local codling moth populations). Nachr. Dtsch. Pflanzenschutzd. 57, 29-34.

Gerlagh, M., Whipps, J. M., Budge, S. P., and Goossen Van De Geijn, H. M. (1996). Efficiency of isolates of Coniothyrium minitans as mycoparasites of Sclerotinia sclerotiorum, Sclerotium cepivorum and Botrytis cinerea on tomato stem pieces. Eur. J. Plant Pathol. 102, 787-793. doi: 10.1007/BF01877154

Govrin, E. M., and Levine, A. (2000). The hypersensitive response facilitates plant infection by the necrotrophic pathogen Botrytis cinerea. Curr. Biol. 10, 751-757. doi: $10.1016 / \mathrm{S} 0960-9822(00) 00560-1$

Govrin, E. M., Rachmilevitch, S., Tiwari, B. S., Soloman, M., and Levine, A. (2006). An elicitor from Botrytis cinerea induces the hypersensitive response in Arabidopsis thaliana and other plants and promotes the gray mold disease. Phytopathology 96, 299-307. doi: 10.1094/PHYTO-96-0299

Guetsky, R., Shtienberg, D., Elad, Y., and Dinoor, A. (2001). Combining biocontrol agents to reduce the variability of biological control. Phytopathology 91, 621-627. doi: 10.1094/PHYTO.2001.91.7.621

Guetsky, R., Shtienberg, D., Elad, Y., Fischer, E., and Dinoor, A. (2002). Improving biological control by combining biocontrol agents each with several mechanisms of disease suppression. Phytopathology 92, 976-985. doi: 10.1094/PHYTO.2002.92.9.976

Gurusiddaiah, S., Weller, D. M., Sarkar, A., and Cook, R. J. (1986). Characterization of an antibiotic produced by a strain of Pseudomonas fluorescens inhibitory to Gaeumannomyces graminis var. tritici and Pythium spp. Antimicrob. Agents Chemother. 29, 488-495. doi: 10.1128/AAC.29.3.488

Harish, S., Manjula, K., and Podile, A. R. (1998). Fusarium udum is resistant to the mycolytic activity of a biocontrol strain of Bacillus subtilis AF 1. FEMS Microbiol. Ecol. 25, 385-390. doi: 10.1111/j.1574-6941.1998.tb00490.x
Harman, G. E. (2006). Overview of mechanisms and uses of Trichoderma spp. Phytopathology 96, 190-194. doi: 10.1094/PHYTO-96-0190

Heilig, U., Delval, P., and Blum, B. (2011). "Registered Biocontrol Products and their use in Europe," in Classical and Augmentative Biological Control Against Diseases and Pests: Critical Status Analysis and Review of Factors Influencing Their Success, ed. P. C. Nicot (IOBC-WPRS), 34-41.

Holt, R. D., and Hochberg, M. E. (1997). When is biological control evolutionarily stable (or is it)? Ecology 78, 1673-1683. doi: 10.1890/00129658(1997)078[1673:WIBCES]2.0.CO;2

Howell, C. R. (2003). Mechanisms employed by Trichoderma species in the biological control of plant diseases: the history and evolution of current concepts. Plant Dis. 87, 4-10. doi: 10.1094/PDIS.2003.87.1.4

Huang, Y., Xie, X., Yang, L., Zhang, J., Li, G., and Jiang, D. (2011). Susceptibility of Sclerotinia sclerotiorum strains different in oxalate production to infection by the mycoparasite Coniothyrium minitans. World J. Microbiol. Biotechnol. 27, 2799-2805. doi: 10.1007/s11274-011-0757-8

Jacobsen, B. J. (2006). "Biological control of plant diseases by phyllosphere applied biological control agents," in Microbial Ecology of Aerial Plant Surfaces, eds M. J. Bailey, A. K. Lilley, T. M. Timms-Wilson, and P. T. N. Spencer-Phillips (Gateshead: Athenaeum Press), 133-147.

Janisiewicz, W. J., and Korsten, L. (2002). Biological control of postharvest diseases of fruits. Annu. Rev. Phytopathol. 40, 411-441. doi: 10.1146/annurev.phyto.40.120401.130158

Janmaat, A. F., and Myers, J. (2003). Rapid evolution and the cost of resistance to Bacillus thuringiensis in greenhouse populations of cabbage loopers, Trichoplusia ni. Proc. R. Soc. B Biol. Sci. 270, 2263-2270. doi: 10.1098/rspb.2003. 2497

Jones, R. W., and Pettit, R. E. (1987). Variation in sensitivity among anastomosis groups in Rhizoctonia solani to the antibiotic gliotoxin. Plant Dis. 71, 34-36. doi: 10.1094/PD-71-0034

Kretschmer, M., Leroch, M., Mosbach, A., Walker, A.-S., Fillinger, S., Mernke, D., et al. (2009). Fungicide-driven evolution and molecular basis of multidrug resistance in field populations of the grey mould fungus Botrytis cinerea. PLoS Pathog. 5:e1000696. doi: 10.1371/journal.ppat.1000696

Lahlali, R., Peng, G., Gossen, B. D., McGregor, L., Yu, F. Q., Hynes, R. K., et al. (2013). Evidence that the biofungicide Serenade (Bacillus subtilis) suppresses clubroot on canola via antibiosis and induced host resistance. Phytopathology 103, 245-254. doi: 10.1094/PHYTO-06-12-0123-R

Leifert, C., Li, H., Chidburee, S., Hampson, S., Workman, S., Sigee, D., et al. (1995). Antibiotic production and biocontrol activity by Bacillus subtilis Cl27 and Bacillus pumilus Cl45. J. Appl. Bacteriol. 78, 97-108. doi: 10.1111/j.13652672.1995.tb02829.x

Levy, E., Eyal, Z., Chet, I., and Hochman, A. (1992). Resistance mechanisms of Septoria tritici to antifungal products of Pseudomonas. Physiol. Mol. Plant Pathol. 40, 163-171. doi: 10.1016/0885-5765(92)90057-3

Li, H., and Leifert, C. (1994). Development of resistance in Botryotinia fuckeliana (de Barry) Whetzel against the biological control agent Bacillus subtilis CL27. Z. Pflanzenkr. Pflanzenschutz 101, 414-418.

Lutz, M. P., Feichtinger, G., Defago, G., and Duffy, B. (2003). Mycotoxigenic Fusarium and deoxynivalenol production repress chitinase gene expression in the biocontrol agent Trichoderma atroviride P1. Appl. Environ. Microbiol. 69, 3077-3084. doi: 10.1128/AEM.69.6.3077-3084.2003

Ma, X., Yang, X., Zeng, F., Yang, L., Yu, D., and Ni, H. (2010). Physcion, a natural anthraquinone derivative, enhances the gene expression of leaf-specific thionin of barley against Blumeria graminis. Pest. Manag. Sci. 66, 718-724. doi: $10.1002 /$ ps. 1933

Mark, G. L., Morrissey, J. P., Higgins, P., and O'gara, F. (2006). Molecular-based strategies to exploit Pseudomonas biocontrol strains for environmental biotechnology applications. FEMS Microbiol. Ecol. 56, 167-177. doi: 10.1111/j.1574-6941.2006.00056.x

Mazzola, M., and Cook, R. J. (1991). Effects of fungal root pathogens on the population dynamics of biocontrol strains of fluorescent pseudomonads in the wheat rhizosphere. Appl. Environ. Microbiol. 57, 2171-2178.

Mazzola, M., Fujimoto, D. K., Thomashow, L. S., and Cook, R. J. (1995). Variation in sensitivity of Gaeumannomyces graminis to antibiotics produced by fluorescent Pseudomonas spp. and effect on biological control of take-all of wheat. Appl. Environ. Microbiol. 61, 2554-2559.

Mazzola, M., Zhao, X., Cohen, M. F., and Raaijmakers, J. M. (2007). Wheat cultivar-specific selection of 2,4-diacetylphloroglucinol-producing fluorescent 
Pseudomonas species from resident soil populations. Phytopathology 97, 1348-1355. doi: 10.1094/PHYTO-97-10-1348

McDonald, B. A. (2014). Using dynamic diversity to achieve durable disease resistance in agricultural ecosystems. Trop. Plant Pathol. 39, 191-196. doi: $10.1590 /$ S1982-56762014000300001

McDonald, B. A., and Linde, C. (2002). Pathogen population genetics, evolutionary potential, and durable resistance. Annu. Rev. Phytopathol. 40, 349-379. doi: 10.1146/annurev.phyto.40.120501.101443

McGaughey, W. H. (1985). Insect resistance to the biological insecticide Bacillus thuringiensis. Science 229, 193-194. doi: 10.1126/science.229.4709. 193

McGaughey, W. H., and Johnson, D. E. (1992). Indianmeal moth (Lepidoptera: pyralidae) resistance to different strains and mixtures of Bacillus thuringiensis. J. Econ. Entomol. 85, 1594-1600. doi: 10.1093/jee/85.5.1594

Milgroom, M. G., and Cortesi, P. (2004). Biological control of chestnut blight with hypovirulence: a critical analysis. Annu. Rev. Phytopathol. 42, 311-338. doi: 10.1146/annurev.phyto.42.040803.140325

Milner, J. L., Silosuh, L., Lee, J. C., He, H. Y., Clardy, J., and Handelsman, J. (1996). Production of kanosamine by Bacillus cereus UW85. Appl. Environ. Microbiol. 62, 3061-3065.

Moore, L. W., and Warren, G. (1979). Agrobacterium radiobacter strain 84 and biological control of crown gall. Annu. Rev. Phytopathol. 17, 163-179. doi: 10.1146/annurev.py.17.090179.001115

Morrissey, J. P., and Osbourn, A. E. (1999). Fungal resistance to plant antibiotics as a mechanism of pathogenesis. Microbiol. Mol. Biol. Rev. 63, 708-724.

Nicot, P. C., Bardin, M., Alabouvette, C., Köhl, J., and Ruocco, M. (2011a). "Potential of biological control based on published research. 1. Protection against plant pathogens of selected crops," in Classical and Augmentative Biological Control Against Diseases and Pests: Critical Status Analysis and Review of Factors Influencing Their Success, ed. P. C. Nicot (IOBC-WPRS), 1-11.

Nicot, P. C., Blum, B., Köhl, J., and Ruocco, M. (2011b). "Conclusions and perspectives," in Classical and Augmentative Biological Control Against Diseases and Pests: Critical Status Analysis and Review of Factors Influencing Their Success, ed. P. C. Nicot (IOBC-WPRS), 68-70.

Notz, R., Maurhofer, M., Dubach, H., Haas, D., and Defago, G. (2002). Fusaric acid-producing strains of Fusarium oxysporum alter 2,4-diacetylphloroglucinol biosynthetic gene expression in Pseudomonas fluorescens CHA0 in vitro and in the rhizosphere of wheat. Appl. Environ. Microbiol. 68, 2229-2235. doi: 10.1128/AEM.68.5.2229-2235.2002

Osbourn, A. E. (1996). Preformed antimicrobial compounds and plant defense against fungal attack. Plant Cell 8, 1821-1831. doi: 10.1105/tpc.8.10. 1821

Otto-Hanson, L. K., Grabau, Z., Rosen, C., Salomon, C. E., and Kinkel, L. L. (2013). Pathogen variation and urea influence selection and success of Streptomyces mixtures in biological control. Phytopathology 103, 34-42. doi: 10.1094/PHYTO-06-12-0129-R

Ownley, B. H., Weller, D. M., and Thomashow, L. S. (1992). Influence of in situ and in vitro $\mathrm{pH}$ on suppression of Gaeumannomyces graminis var tritici by Pseudomonas fluorescens 2-79. Phytopathology 82, 178-184. doi: 10.1094/Phyto$82-178$

Paulitz, T. C., and Belanger, R. R. (2001). Biological control in greenhouse systems. Annu. Rev. Phytopathol. 39, 103-133. doi: 10.1146/annurev.phyto.39.1.103

Peever, T. L., Liu, Y.-C., Cortesi, P., and Milgroom, M. G. (2000). Variation in tolerance and virulence in the chestnut blight fungushypovirus interaction. Appl. Environ. Microbiol. 66, 4863-4869. doi: 10.1128/AEM.66.11.4863-4869.2000

Quidde, T., Osbourn, A. E., and Tudzynski, P. (1998). Detoxification of alphatomatine by Botrytis cinerea. Physiol. Mol. Plant Pathol. 52, 151-165. doi: 10.1006/pmpp.1998.0142

Raaijmakers, J. M., Paulitz, T. C., Steinberg, C., Alabouvette, C., and MoënneLoccoz, Y. (2009). The rhizosphere: a playground and battlefield for soilborne pathogens and beneficial microorganisms. Plant Soil 321, 341-361. doi: 10.1007/s11104-008-9568-6

Raaijmakers, J. M., Vlami, M., and De Souza, J. T. (2002). Antibiotic production by bacterial biocontrol agents. J. Gen. Mol. Microbiol. 81, 537-547.

Randoux, B., Renard, D., Nowak, E., Sanssené, J., Courtois, J., Durand, R., et al. (2006). Inhibition of Blumeria graminis f. sp. tritici germination and partial enhancement of wheat defenses by Milsana. Phytopathology 96, 1278-1286. doi: 10.1094/PHYTO-96-1278
Rivera-Varas, V. V., Freeman, T. A., Gudmestad, N. C., and Secor, G. A. (2007). Mycoparasitism of Helminthosporium solani by Acremonium strictum. Phytopathology 97, 1331-1337. doi: 10.1094/PHYTO-97-101331

Ruocco, M., Woo, S., Vinale, F., Lanzuise, S., and Lorito, M. (2011). "Identified difficulties and conditions for field success of biocontrol. 2. Technical aspects: factors of efficacy," in Classical and Augmentative Biological Control Against Diseases and Pests: Critical Status Analysis and Review Of Factors Influencing Their Success, ed. P. C. Nicot (IOBC-WPRS), 45-57.

Sansone, G., Rezza, I., Calvente, V., Benuzzi, D., and Sanz De Tosetti, M. I. (2005). Control of Botrytis cinerea strains resistant to iprodione in apple with rhodotorulic acid and yeasts. Postharvest Biol. Technol. 35, 245-251. doi: 10.1016/j.postharvbio.2004.09.005

Sansone, G., Rezza, I., Fernandez, G., Calvente, V., Benuzzi, D., and Sanz, M. I. (2011). Inhibitors of polygalacturonase and laccase of Botrytis cinerea and their application to the control of this fungus. Int. Biodeterior. Biodegradation 65, 243-247. doi: 10.1016/j.ibiod.2010.09.010

Santamaria, O., Gonzalez, M. A., Pajaresand, J. A., and Diez, J. J. (2007). Effect of fungicides, endophytes and fungal filtrates on in vitro growth of Spanish isolates of Gremmeniella abietina. For. Pathol. 37, 251-262. doi: 10.1111/j.14390329.2007.00498.x

Sauphanor, B., Berling, M., Toubon, J.-F., Reyes, M., Delnatte, J., and Allemoz, P. (2006). Carpocapse des pommes: cas de résistance au virus de la granulose en vergers biologiques. Phytoma 590, 24-27.

Sbaghi, M., Jeandet, P., Bessis, R., and Leroux, P. (1996). Degradation of stilbene-type phytoalexins in relation to the pathogenicity of Botrytis cinerea to grapevines. Plant Pathol. 45, 139-144. doi: 10.1046/j.1365-3059.1996.d01101.x

Schnabel, E. L., and Jones, A. L. (2001). Isolation and characterization of Five Erwinia amylovora bacteriophages and assessment of phage resistance in strains of Erwinia amylovora. Appl. Environ. Microbiol. 67, 59-64. doi: 10.1128/AEM.67.1.59-64.2001

Schoonbeek, H., Del Sorbo, G., and De Waard, M. A. (2001). The ABC transporter BcatrB affects the sensitivity of Botrytis cinerea to the phytoalexin resveratrol and the fungicide fenpiclonil. Mol. Plant Microbe Interact. 14, 562-571. doi: 10.1094/MPMI.2001.14.4.562

Schoonbeek, H., Raaijmakers, J. M., and De Waard, M. A. (2002). Fungal ABC transporters and microbial interactions in natural environments. Mol. Plant Microbe Interact. 15, 1165-1172. doi: 10.1094/MPMI.2002.15.11.1165

Schoonbeek, H. J., Jacquat-Bovet, A. C., Mascher, F., and Metraux, J. P. (2007). Oxalate-degrading bacteria can protect Arabidopsis thaliana and crop plants against Botrytis cinerea. Mol. Plant Microbe Interact. 20, 1535-1544. doi: 10.1094/MPMI-20-12-1535

Schouten, A., Maksimova, O., Cuesta-Arenas, Y., Van Den Berg, G., and Raaijmakers, J. M. (2008). Involvement of the ABC transporter BcAtrB and the laccase BcLCC2 in defence of Botrytis cinerea against the broad-spectrum antibiotic 2,4-diacetylphloroglucinol. Environ. Microbiol. 10, 1145-1157. doi: 10.1111/j.1462-2920.2007.01531.x

Schouten, A., Van Den Berg, G., Edel-Hermann, V., Steinberg, C., Gautheron, N., Alabouvette, C., et al. (2004). Defense responses of Fusarium oxysporum to 2,4-diacetylphloroglucinol, a broad-spectrum antibiotic produced by Pseudomonas fluorescens. Mol. Plant Microbe Interact. 17, 1201-1211. doi: 10.1094/MPMI.2004.17.11.1201

Shibu, M. A., Lin, H. S., Yang, H. H., and Peng, K. C. (2012). Trichoderma harzianum ETS 323-mediated resistance in Brassica oleracea var. capitata to Rhizoctonia solani involves the novel expression of a glutathione s-transferase and a deoxycytidine deaminase. J. Agric. Food Chem. 60, 10723-10732. doi: $10.1021 /$ jf3025634

Shtienberg, D., and Elad, Y. (1997). Incorporation of weather forecasting in integrated, biological-chemical management of Botrytis cinerea. Phytopathology 87, 332-340. doi: 10.1094/PHYTO.1997.87.3.332

Stockwell, V. O., Kawalek, M. D., Moore, L. W., and Loper, J. E. (1996). Transfer of pAgK84 from the biocontrol agent Agrobacterium radiobacter K84 to under field conditions. Phytopathology 86, 31-37. doi: 10.1094/Phyto-86-31

Tabashnik, B. E. (1994). Evolution of resistance to Bacillus thuringiensis. Annu. Rev. Entomol. 39, 47-79. doi: 10.1146/annurev.en.39.010194.000403

Turner, G. J., and Tribe, H. T. (1976). On Coniothyrium minitans and its parasitism of Sclerotinia species. Trans. Br. Mycol. Soc. 66, 97-105. doi: 10.1016/S00071536(76)80098-8 
VAN Zyl, F. G. H., Strijdom, B. W., and Staphorst, J. L. (1986). Susceptibility of Agrobacterium tumefaciens strains to two agrocin-producing Agrobacterium strains. Appl. Environ. Microbiol. 52, 234-238.

Vitale, A., Cirvilleri, G., Castello, I., Aiello, D., and Polizzi, G. (2012). Evaluation of Trichoderma harzianum strain T22 as biological control agent of Calonectria pauciramosa. BioControl 57, 687-696. doi: 10.1007/s10526-0119423-1

Vorholt, J. A. (2012). Microbial life in the phyllosphere. Nat. Rev. Microbiol. 10, 828-840. doi: 10.1038/nrmicro2910

Wang, Y., Lim, L., Diguistini, S., Robertson, G., Bohlmann, J., and Breuil, C. (2013). A specialized ABC efflux transporter GcABC-G1 confers monoterpene resistance to Grosmannia clavigera, a bark beetle-associated fungal pathogen of pine trees. New Phytol. 197, 886-898. doi: 10.1111/nph. 12063

Whipps, J. M., Sreenivasaprasad, S., Muthumeenakshi, S., Rogers, C. W., and Challen, M. P. (2008). Use of Coniothyrium minitans as a biocontrol agent and some molecular aspects of sclerotial mycoparasitism. Eur. J. Plant Pathol. 121, 323-330. doi: 10.1007/s10658-0079238-1
Wiesel, L., Newton, A. C., Elliott, I., Booty, D., Gilroy, E. M., Birch, P. R. J., et al. (2014). Molecular effects of resistance elicitors from biological origin and their potential for crop protection. Front. Plant Sci. 5:655. doi: 10.3389/fpls.2014.00655

Yang, X. J., Yang, L. J., Zeng, F. S., Xiang, L. B., Wang, S. N., Yu, D. Z., et al. (2008). Distribution of baseline sensitivities to natural product physcion among isolates of Sphaerotheca fuliginea and Pseudoperonospora cubensis. Plant Dis. 92, 1451-1455. doi: 10.1094/PDIS-92-10-1451

Conflict of Interest Statement: The authors declare that the research was conducted in the absence of any commercial or financial relationships that could be construed as a potential conflict of interest.

Copyright (C) 2015 Bardin, Ajouz, Comby, Lopez-Ferber, Graillot, Siegwart and Nicot. This is an open-access article distributed under the terms of the Creative Commons Attribution License (CC BY). The use, distribution or reproduction in other forums is permitted, provided the original author(s) or licensor are credited and that the original publication in this journal is cited, in accordance with accepted academic practice. No use, distribution or reproduction is permitted which does not comply with these terms. 